\title{
Dynamic mechanical analysis and thermal analysis of untreated Coccinia indica fiber composites
}

\author{
S. Balu(1), *), P.S. Sampath ${ }^{2)}$, M. Bhuvaneshwaran ${ }^{3)}$, G. Chandrasekar ${ }^{1)}$, A. Karthik ${ }^{4)}$, Suresh Sagadevan ${ }^{5)}$ \\ DOI: dx.doi.org/10.14314/polimery.2020.5.3
}

\begin{abstract}
A natural fiber reinforced polymer matrix composites (FRCs) was prepared by the compression molding method. The natural fiber named Coccinia indica (CI) was employed to fabricate FRCs. The impact of fiber length on storage modulus, loss modulus and loss of weight in the FRCs were determined using dynamic mechanical analysis (DMA) and thermogravimetric analysis (TGA). The results revealed that a fiber length of $40 \mathrm{~mm}$ shows better storage modulus and nominal loss modulus owing to the higher interfacial bonding between fiber and matrix. In other investigated fiber lengths, the storage modulus is poor and loss modulus is high, which is due to inefficient stress transfer.
\end{abstract}

Keywords: polymer matrix composites, Coccinia indica fiber (CIF), compression molding, DMA, TGA, Coccinia indica fiber reinforced composites (CIFRCs).

\section{Dynamiczna analiza mechaniczna i analiza termiczna kompozytów z niepoddanymi obróbce włóknami Coccinia indica}

Streszczenie: Metodą wytłaczania przygotowano próbki kompozytów (FRC) na osnowie polimerowej wzmocnionej włóknami naturalnymi Coccinia indica (CI). Wpływ długości zastosowanych włókien na moduł zachowawczy, moduł stratności i ubytek masy badanych FRC oceniano za pomocą dynamicznej analizy mechanicznej (DMA) i analizy termograwimetrycznej (TGA). Stwierdzono, że kompozyty z udziałem włókien o długości $40 \mathrm{~mm}$ wykazują korzystniejszy moduł zachowawczy i nominalny moduł stratności, dzięki lepszemu wiązaniu międzyfazowemu włókna z osnową. W wypadku kompozytów z zawartością włókien o innych długościach moduł zachowawczy jest mały, a moduł stratności duży, co wynika z nieefektywnego przenoszenia naprężeń.

Słowa kluczowe: kompozyty na osnowie polimerowej, włókno Coccinia indica (CIF), formowanie metodą wytłaczania, DMA, TGA, kompozyty wzmocnione włóknem Coccinia indica (CIFRC).

A fiber reinforced polymer (FRP) is a composite material comprising a polymer matrix embedded with highquality fibers [1]. The material that is inserted is called reinforcement and where it is installed is known as a matrix $[2,3]$. Generally, the polymer can be characterized into two classes, thermoplastics and thermosetting [4]. Similarly, fibers can be classified as natural fiber and synthetic fiber $[5,6]$. The use of fibers such as natural or synthetic as an enhancing element in a polymer matrix makes the polymer suitable for many applications [7, 8]. The characteristics of fiber-reinforced composites called fibrous composite substances are especially dependent upon the properties of the fiber and its microstructural parameters such as the diameter and length of the fiber $[9,10]$, fiber propagation, fiber orientation and fiber volume division [11-17].

From the literature, it was found that no work has been reported on the selected candidate natural fiber composite. Hence, it is planned to fabricate the biodegradable FRCs by mixing the natural fiber (Coccinia indica) and synthetic (polyester) resin. Different lengths of fibers have been used in the fabrication to determine the most suit-

1) PSNA College of Engineering and Technology, Department of Mechanical Engineering, Dindigul 624 622, Tamilnadu, India.

2) K.S. Rangasamy College of Technology, Department of Mechanical Engineering, KSR Kalvi Nagar, Tiruchengode 637 215, Tamilnadu, India.

3) K.S.R. College of Engineering, Department of Mechanical Engineering, KSR Kalvi Nagar, Tiruchengode 637 215, Tamilnadu, India.

4) SSM College of Engineering, Department of Mechanical Engineering, Salem Main Road, Komarapalayam 638 183, Tamilnadu, India.

5) University of Malaya, Nanotechnology and Catalysis Research Center, 50603 Kuala Lumpur, Malaysia.

*) Author for correspondence: balusharma@gmail.com 
able fiber length for the successful composite manufacturing.

\section{EXPERIMENTAL PART}

\section{Materials and processing}

The utilized fiber in this work is Coccinia indica (CI) shown in Fig. 1 while Fig. 2 depicts the scanning electron microscope (SEM) photograph of the fiber at a different magnification. The CI plants were collected from Chinnachettiyapalayam village, Erode district, Tamil Nadu, South India, which is a medicinal plant under the family of Cucurbitaceae [18, 19]. The physiochemical properties of the CI fiber are presented in Table 1.

The matrix used in this research, unsaturated polyester [20], depicts the properties in both liquid and cured states. The curing catalyst used in this work is methyl

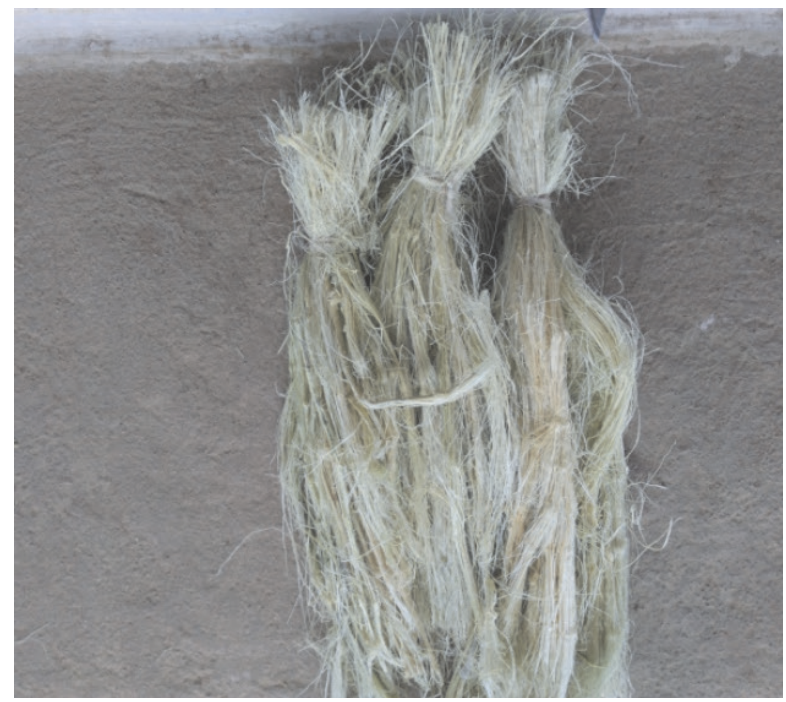

Fig. 1. Coccinia indica (CI) fiber

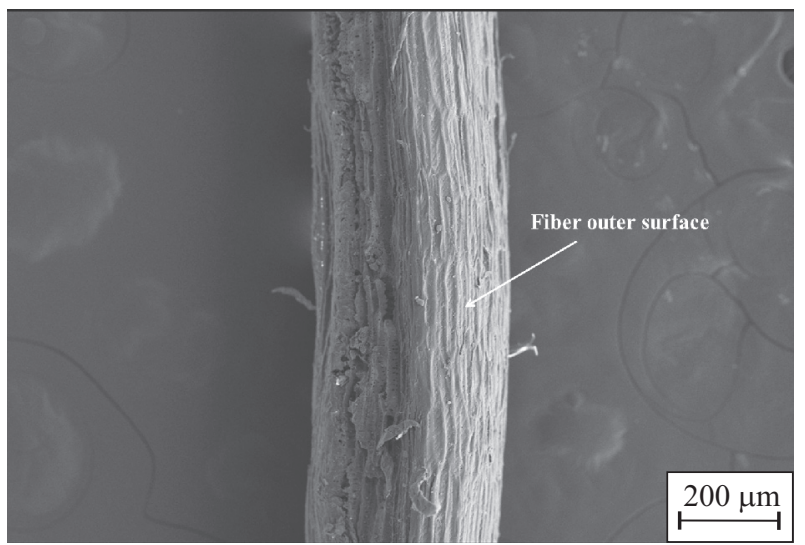

Fig. 2. SEM photograph of CI fiber in different magnification rate ethyl ketone peroxide (MEKP). The function of this catalyst in the composite is to speed up the binding between fiber and resin. The accelerator utilized in these experiments is cobalt naphthenate, which is used to alter the chemical bonds and to speed the chemical process.

\section{Sample preparation}

The composites were fabricated using a compression molding process [21]. A mold size of $300 \times 300 \times 3 \mathrm{~mm}$ was used to manufacture the composites. Before molding, the internal surface of the mold was coated with a wax polish to enable the ease of removing the polymer composites from the mold. The CI fiber was hewed into various lengths such as 10, 20, 30, 40 and $50 \mathrm{~mm}$. During the curing process, a compressive force of $0.5 \mathrm{MPa}$ was applied to the material for about 24 hours. The polyester was used as a matrix material and 2\% MEKP with $0.5 \%$ cobalt naphthenate were employed as a catalyst and accelerator, respectively.

\section{Methods of testing}

\section{Dynamic mechanical analysis (DMA)}

DMA is a generally employed technique to measure the temperature dependence properties such as damping factor $(\tan \delta)$, loss modulus $\left(G^{\prime \prime}\right)$ and storage modulus $\left(G^{\prime}\right)$ [22]. The apparatus DMA 6100 was utilized for the experiments. The fabricated Coccinia indica fiber reinforced composites (CIFRCs) were sectioned into $50 \times 10 \times 3 \mathrm{~mm}$ sized pieces and they were then used for the DMA test. The tests were conducted using a three-point bowing framework. The CIFRCs were dried at a fixed frequency of $1.0 \mathrm{~Hz}$ (oscillation amplitude $0.3 \mathrm{~mm}$ ) and a plummeted

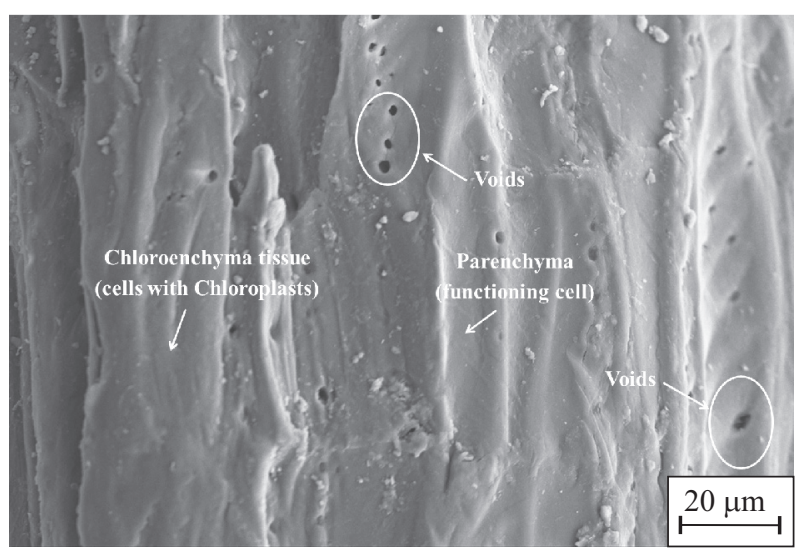

T a b l e 1. Physiochemical properties of the CI fiber

\begin{tabular}{c|c|c|c|c|c|c|c}
\hline $\begin{array}{c}\text { Cellulose } \\
\%\end{array}$ & $\begin{array}{c}\text { Hemicellulose } \\
\%\end{array}$ & $\begin{array}{c}\text { Lignin } \\
\%\end{array}$ & $\begin{array}{c}\text { Wax } \\
\%\end{array}$ & $\begin{array}{c}\text { Ash } \\
\%\end{array}$ & $\begin{array}{c}\text { Moisture } \\
\%\end{array}$ & $\begin{array}{c}\text { Density } \\
\mathrm{kg} / \mathrm{m}^{3}\end{array}$ & $\begin{array}{c}\text { Elongation } \\
\%\end{array}$ \\
\hline 72.6 & 15.2 & 21.2 & 0.2 & 2.4 & 9.0 & 1298 & 4.3 \\
\hline
\end{tabular}


heating rate of $0.08^{\circ} \mathrm{C} / \mathrm{s}$. The samples were evaluated in the temperature range of $35-185^{\circ} \mathrm{C}$.

\section{Thermogravimetric analysis (TGA)}

To assess the thermal stability and physicochemical properties of the fabricated composite, TGA was performed on the samples taken from CIFRCs [23]. In this TGA test, a change in thermal stability was evaluated in terms of percentage mass loss as a function of temperature. In the study, TGA measures the loss of mass in the developed CIFRC materials as a component of temperature (or time) under a controlled atmosphere to determine the thermal strength, as well as composition. As a rule, the thermal analysis of the material is completed in order to assess the chemical, physical and basic changes happening in a material under a forced change in temperature.

\section{RESULTS AND DISCUSSIONS}

\section{Dynamic properties}

In this research work, the dynamic properties of CIFRCs such as storage modulus, loss modulus and damping factor (loss factor) were assessed using DMA. The storage modulus $\left(G^{\prime}\right)$ indicates the stiffness of the viscoelastic material and this is proportional to the energy stored during a loading cycle. The loss modulus $\left(G^{\prime \prime}\right)$ characterizes the capability of a material to dissipate energy as heat, owing to motions inside the viscous material itself. The damping factor $(\tan \delta)$ is defined as the ratio of loss modulus to storage modulus.

Figure 3 and Table 2 represent the effect of temperature on the $G^{\prime}$ of pure polyester and different fiber length CIFRCs. It is seen in Fig. 3 that, in all investigated samples, the storage modulus reduces with higher temperatures. The pure polyester shows the smallest storage modulus over the temperature range compared with the tested CIFRCs. It is inferred from the figure that the CI reinforcement can build the storage modulus of CIFRCs because of the stiffening effect of the fiber within the matrix. Faruk et al. [1] clearly mentioned that a lower $L / D$ ratio (length/diameter) can increase the strength of the fiber owing to the presence of fewer defects in the fiber. Further, it is revealed from the figure that the highest $G^{\prime}$ up to around $120^{\circ} \mathrm{C}$ is for the $\mathrm{CI}$ length of $40 \mathrm{~mm}$, and the lowest for the length of $50 \mathrm{~mm}$. Also, for the CI length of $10 \mathrm{~mm}$, the $G^{\prime}$ is lower than for the lengths of $20 \mathrm{~mm}$ and $40 \mathrm{~mm}$ which is due to the distribution and orientation of the reinforcing fibers [24].

Generally, the DMA result has two discrete regions called a glassy plateau and rubbery plateau which is based on the temperature. The region below $110^{\circ} \mathrm{C}$ is named the glassy plateau (mobilization) and the temperature above $110^{\circ} \mathrm{C}$ is named the rubbery plateau (plasticized). It is revealed from Fig. 4 that the $G^{\prime \prime}$ of the pure

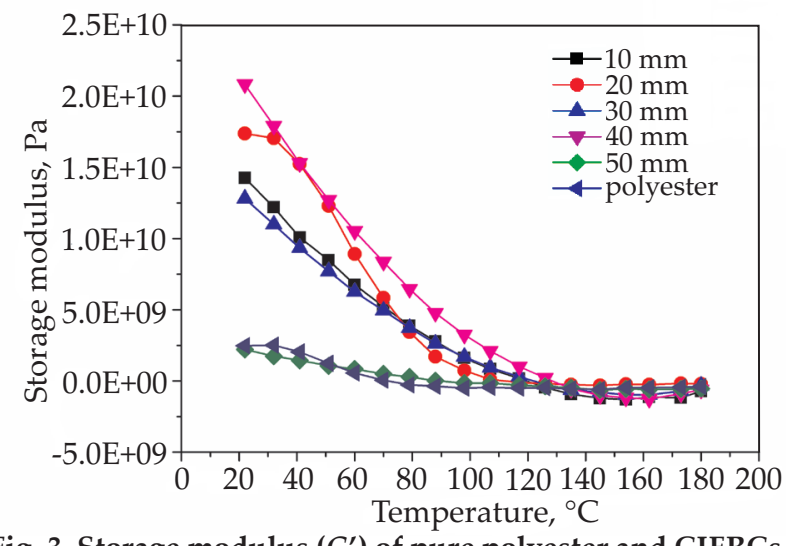

Fig. 3. Storage modulus $\left(G^{\prime}\right)$ of pure polyester and CIFRCs

T a b 1 e 2. Results of storage modulus $\left(G^{\prime}\right)$ of composites with fiber various length vs. temperature

\begin{tabular}{|c|c|c|c|c|c|c|}
\hline \multirow{3}{*}{$\begin{array}{c}\text { Temperature } \\
{ }^{\circ} \mathrm{C}\end{array}$} & \multicolumn{5}{|c|}{ Fiber length, mm } & \multirow{2}{*}{ Polyester } \\
\hline & 10 & 20 & 30 & 40 & 50 & \\
\hline & \multicolumn{6}{|c|}{ Storage modulus, $\mathrm{Pa}$} \\
\hline 22 & $1.43 \mathrm{E}+10$ & $1.74 \mathrm{E}+10$ & $1.28 \mathrm{E}+10$ & $2.08 \mathrm{E}+10$ & $2.21 \mathrm{E}+09$ & $2.47 \mathrm{E}+09$ \\
\hline 98 & $1.60 \mathrm{E}+09$ & $7.40 \mathrm{E}+08$ & $1.70 \mathrm{E}+09$ & $3.25 \mathrm{E}+09$ & $1.51 \mathrm{E}+08$ & $4.97 \mathrm{E}+08$ \\
\hline 180 & 7.16E+08 & $2.11 \mathrm{E}+08$ & $3.32 \mathrm{E}+08$ & $6.24 \mathrm{E}+08$ & $5.30 \mathrm{E}+08$ & $3.91 \mathrm{E}+08$ \\
\hline
\end{tabular}

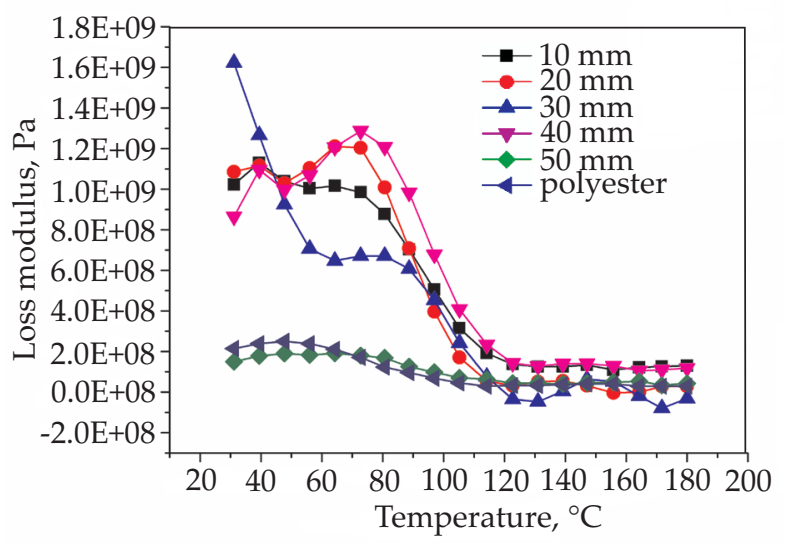

Fig. 4. Loss modulus $\left(G^{\prime \prime}\right)$ of pure polyester and CIFRCs

T a b l e 3. Results of storage modulus $\left(G^{\prime \prime}\right)$ of composites with fiber various length $v s$. temperature

\begin{tabular}{|c|c|c|c|c|c|c|}
\hline \multirow{3}{*}{$\begin{array}{c}\text { Temperature } \\
{ }^{\circ} \mathrm{C}\end{array}$} & \multicolumn{5}{|c|}{ Fiber length, mm } & \multirow{2}{*}{ Polyester } \\
\hline & 10 & 20 & 30 & 40 & 50 & \\
\hline & \multicolumn{6}{|c|}{ Loss modulus, $\mathrm{Pa}$} \\
\hline 32 & $1.02 \mathrm{E}+09$ & $1.09 \mathrm{E}+09$ & $1.62 \mathrm{E}+09$ & $8.65 \mathrm{E}+08$ & $1.51 \mathrm{E}+08$ & $2.15 \mathrm{E}+08$ \\
\hline 97 & $5.05 \mathrm{E}+08$ & $3.96 \mathrm{E}+08$ & $4.53 \mathrm{E}+08$ & $6.78 \mathrm{E}+08$ & $9.82 \mathrm{E}+07$ & $6.85 \mathrm{E}+07$ \\
\hline 180 & $1.30 \mathrm{E}+08$ & $2.79 \mathrm{E}+07$ & $-3.09 \mathrm{E}+07$ & $1.18 \mathrm{E}+08$ & $4.27 \mathrm{E}+07$ & $2.89 \mathrm{E}+07$ \\
\hline
\end{tabular}

polyester is lower than $G^{\prime \prime}$ of the CIFRCs in the glass transition region. This is because of the free molecular mobility of the polymer chains that can break the cross-linking between the molecular chains. Further, it is identified from the figure that the reinforcement of $\mathrm{CI}$ into polyester increased the $G^{\prime \prime}$ drastically. Among the various fiber 


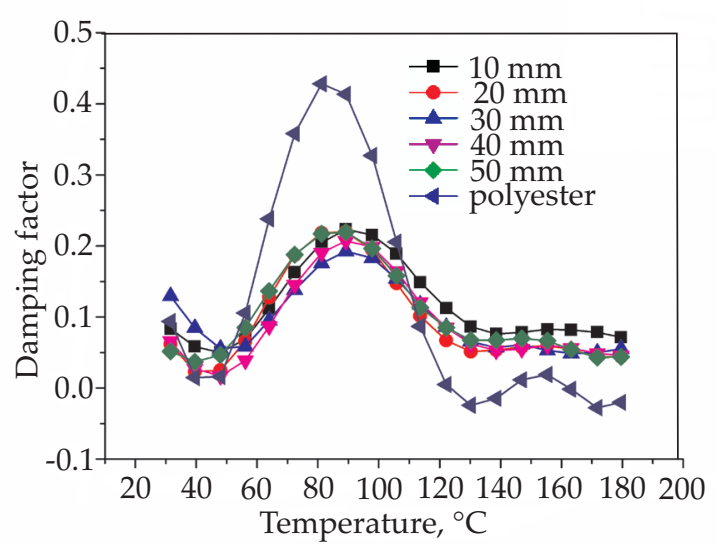

Fig. 5. Damping factor (tan $\delta$ ) of pure polyester and CIFRCs

T a b l e 4. Results of damping factor (tan $\delta$ ) of composites with fiber various length $v s$. temperature

\begin{tabular}{c|c|c|c|c|c|c}
\hline \multirow{2}{*}{$\begin{array}{c}\text { Temperature } \\
{ }^{\circ} \mathrm{C}\end{array}$} & \multicolumn{5}{|c|}{ Fiber length, mm } & \multirow{2}{*}{ Polyester } \\
\cline { 2 - 6 } & 10 & 20 & 30 & 40 & 50 & \\
\cline { 2 - 6 } & \multicolumn{7}{|c}{ Damping factor } \\
\hline 32 & 0.083 & 0.061 & 0.129 & 0.065 & 0.051 & 0.093 \\
98 & 0.215 & 0.194 & 0.182 & 0.198 & 0.196 & 0.327 \\
180 & 0.071 & 0.043 & 0.055 & 0.045 & 0.043 & 0.020 \\
\hline
\end{tabular}

lengths, $40 \mathrm{~mm}$ fiber length reinforced composite has shown higher $G^{\prime \prime}$ in the glassy plateau due to the higher interfacial bonding between fiber and matrix. However, it plummeted steeply at increased temperatures. Further, it is noted from Fig. 4 that all the curves of the samples seem to merge after the glassy plateau temperature due to the softening effect at the interface at higher temperatures [24].

Figure 4 shows the loss modulus ( $\left.G^{\prime \prime}\right)$ of pure polyester and different fiber length CIFRCs. It is identified from the graph that the $G^{\prime \prime}$ of pure polyester and higher fiber length is low owing to the lack of heat dissipation. The fiber length of 10 to $40 \mathrm{~mm}$ reinforced CIFRCs $G^{\prime \prime}$ have fluctuations up to the temperature of $80^{\circ} \mathrm{C}$ and beyond that temperature a sharp fall in $G^{\prime \prime}$ was observed. This is due to free rotation around the mainchain bonds in the polymer chains. The $30 \mathrm{~mm}$ fiber length was found to provide the highest value up to around $40^{\circ} \mathrm{C}$. This could be due to the variation in the physical bond between the fiber and matrix [23].

Figure 5 shows the damping factor (tan $\delta$ ) of all examined samples. The pure polyester $\tan \delta$ is higher than others in the glassy plateau because of more degree of freedom at the atomic level. Only a small difference in the $\tan \delta$ values are found among all the fiber lengths. However, the nominal damping factor was observed at $30 \mathrm{~mm}$ fiber length reinforced composites which were found as a critical length $\left(L_{c}\right)$ of CIFRCs. The fiber length above and below the $L_{c}$ showed a slight increase and decrease in $\tan \delta$ which is due to a faster dissipation of energy. The obtained results are in agreement with the results obtained by V.S. Sreenivasan et al. [17].

\section{TGA analysis}

The thermal behavior of the CIFs was envisaged using TG and DTG curves obtained from the thermogravimetry test as given in Fig. 6. It was identified from the figure that the degradation of CIFs happened in different stages [25]. In the first stage, temperatures up to $70^{\circ} \mathrm{C}$, evaporation of moisture content present in the CIFs occurred with a mass change of $8.9 \%$. In the second stage, temperature between $68^{\circ} \mathrm{C}$ to $203^{\circ} \mathrm{C}$, the remaining moisture and part of the hemicellulose content removal happened with a mass change of $18 \%$. Similarly, in the third stage, between $203^{\circ} \mathrm{C}$ and $371.1^{\circ} \mathrm{C}$, the degradation of cellulose and the remaining part of lignin occured with a mass change of $50 \%$ [26]. In the final stage, above $371.1^{\circ} \mathrm{C}$, the degradation of part of the cellulose and lignin occured and the mass change was observed to be $8 \%$.

Further in this study, TGA was carried out to evaluate the thermal stability of pure polyester and different fiber length reinforced CIFRCs under a controlled environment and the results are shown in Fig. 7. It was found from the figure that there was no significant deviation in the degradation curves of raw polymer and investigated

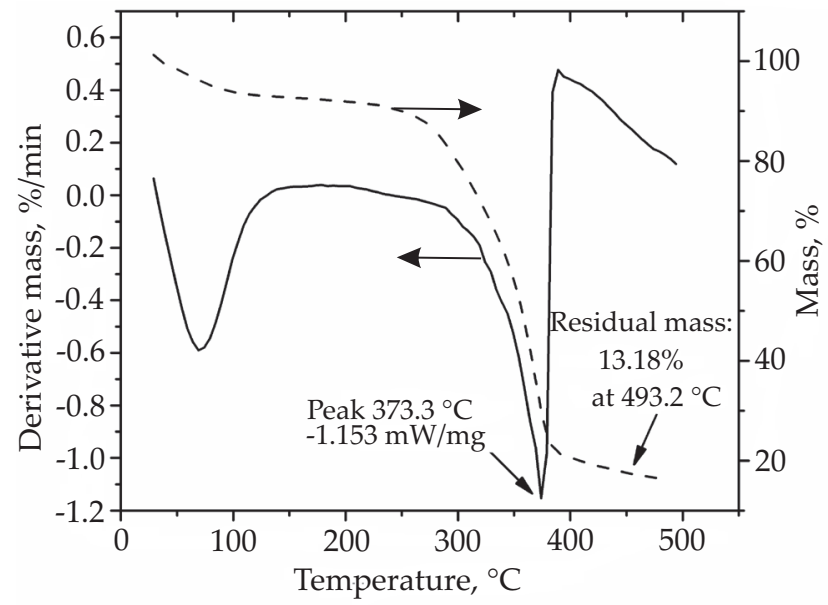

Fig. 6. Thermogravimetric analysis of CIFs

$\mathrm{T}$ a b 1 e 5. Results of thermogravimetric analysis of CIF

\begin{tabular}{c|c|c|c|c|c|c|c|c|c|c|c|c}
\hline $\begin{array}{c}\mathrm{T}_{1} \\
{ }^{\circ} \mathrm{C}\end{array}$ & $\begin{array}{c}\mathrm{DTG}_{1} \\
\% / \mathrm{min}\end{array}$ & $\begin{array}{c}\mathrm{TG}_{1} \\
\%\end{array}$ & $\begin{array}{c}\mathrm{T}_{2} \\
{ }^{\circ} \mathrm{C}\end{array}$ & $\begin{array}{c}\mathrm{DTG}_{2} \\
\% / \mathrm{min}\end{array}$ & $\begin{array}{c}\mathrm{TG}_{2} \\
\%\end{array}$ & $\begin{array}{c}\mathrm{T}_{3} \\
{ }^{\circ} \mathrm{C}\end{array}$ & $\begin{array}{c}\mathrm{DTG}_{3} \\
\% / \mathrm{min}\end{array}$ & $\begin{array}{c}\mathrm{TG}_{3} \\
\%\end{array}$ & $\begin{array}{c}\mathrm{T}_{4} \\
{ }^{\circ} \mathrm{C}\end{array}$ & $\begin{array}{c}\mathrm{DTG}_{4} \\
\% / \mathrm{min}\end{array}$ & $\begin{array}{c}\mathrm{TG}_{4} \\
\%\end{array}$ \\
\hline 29 & 0.06 & 100 & 154 & 0.03 & 92.6 & 279 & -0.03 & 86.2 & 404 & 0.43 & 20.3 \\
79 & -0.54 & 95.2 & 204 & 0.03 & 91.8 & 329 & -0.29 & 67.8 & 454 & 0.25 & 17.4 \\
149 & 0.03 & 92.7 & 274 & -0.03 & 87.3 & 399 & 0.44 & 20.7 & 474 & 0.15 & 15.5 \\
\hline
\end{tabular}




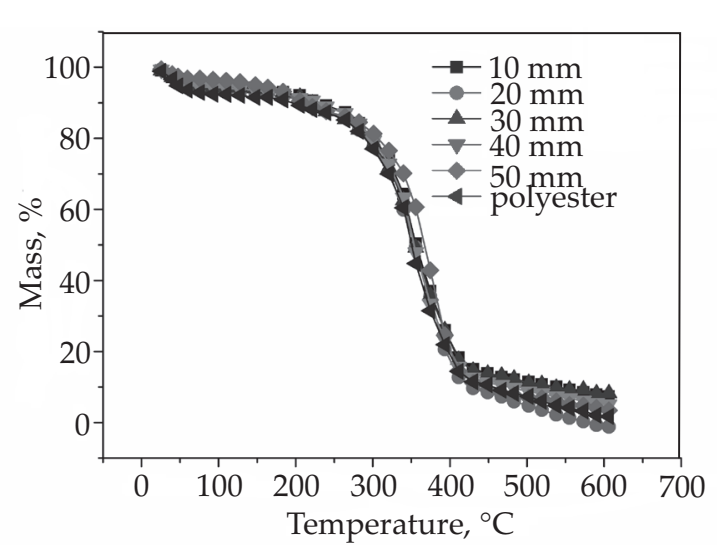

Fig. 7. Mass loss of pure polyester and CIFRCs with varying fiber lengths

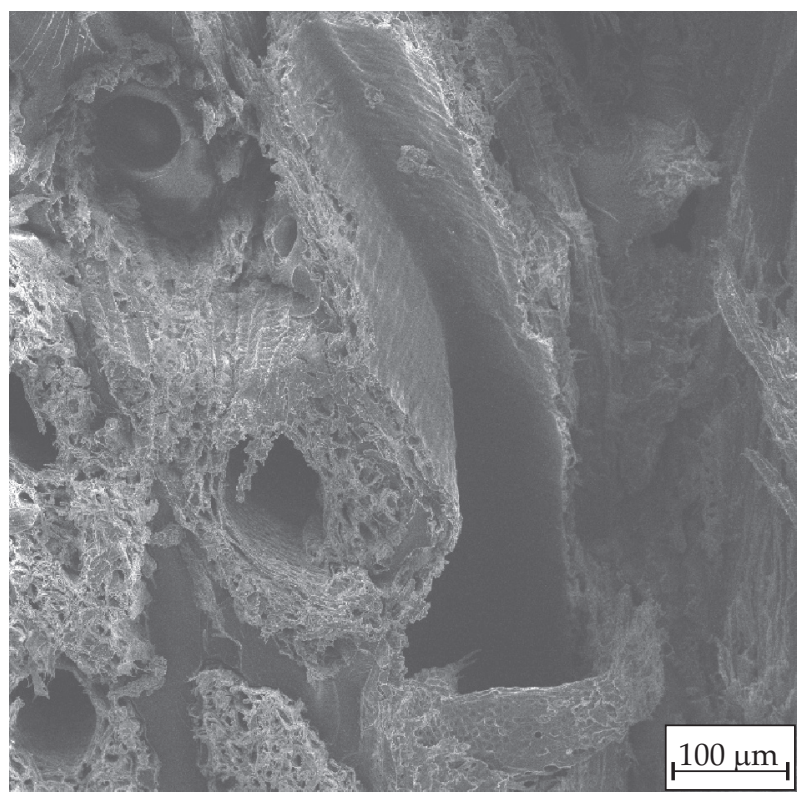

Fig. 8. SEM fractography of flexural fractured CIFRCs

CIFRCs. Likewise, it was noted from the figure that, up to $400^{\circ} \mathrm{C}$, the degradation curves of all samples are sharp, which is due to the level of water loading in the composite [23]. Further, it is observed that above $400^{\circ} \mathrm{C}$, there is a significant improvement in thermal stability. It could be reasoned that, at the higher range of temperature, the fiber-matrix interfacial bonding and the presence of cellulose and lignin offer the withstanding capability of heat. Accordingly, the $30 \mathrm{~mm}$ fiber length $\left(L_{c}\right)$ suffered the minimum mass loss in the last stage of degradation, as seen in Fig. 7.

Figure 8 shows the SEM fractograph of the flexural fracture surface of the fabricated composite $(40 \mathrm{~mm}$ fiber length). It is revealed from the figure that fiber and matrix fractures have happened during flexural loading. Further, it was observed that interfacial bonding is good in the fabricated composite, which is evident by skimpy voids in the fractography.

Figure 9 depicts the SEM fractography of the impact fracture surface of the fabricated composite. It is found from the figure that more matrix debris and voids were
T a b l e 6. Results of mass loss of composites with fiber various length $v$ s. temperature

\begin{tabular}{c|c|c|c|c|c|c}
\hline \multirow{2}{*}{$\begin{array}{c}\text { Temperature } \\
{ }^{\circ} \mathrm{C}\end{array}$} & \multicolumn{5}{|c|}{ Fiber length, mm } & \multirow{2}{*}{ Polyester } \\
\cline { 2 - 6 } & 10 & 20 & 30 & 40 & 50 & \\
\cline { 2 - 6 } & \multicolumn{6}{|c}{ Mass, \% } \\
\hline 26 & 99.1 & 99.4 & 99.1 & 99.3 & 99.4 & 98.9 \\
110 & 94.8 & 93.3 & 94.3 & 94.2 & 96.2 & 92.4 \\
411 & 18.2 & 12.7 & 17.6 & 15.6 & 14.5 & 14.4 \\
502 & 11.4 & 4.7 & 11.1 & 8.7 & 7.0 & 7.4 \\
606 & 7.3 & 1.2 & 8.2 & 5.1 & 3.4 & 1.7 \\
\hline
\end{tabular}

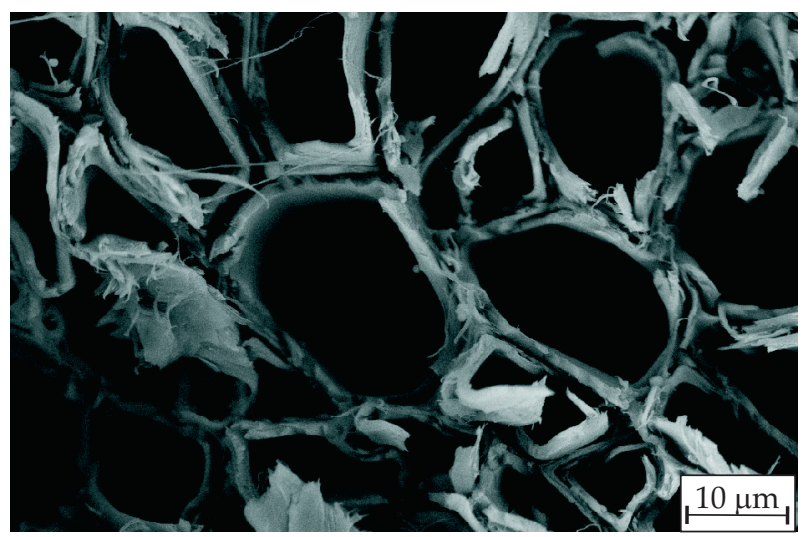

Fig. 9. SEM fractography of impact fractured $40 \mathrm{~mm}$ fiber length in CIFRCs

present due to fiber pullout, which could be the reason for impact loading.

\section{CONCLUSIONS}

- The Coccinia indica (CI) short fiber reinforced polyester matrix composite was fabricated successfully using a compression molding process with beneficial dynamic mechanical and thermal properties.

- The introduction of CI fiber into the polyester matrix increased the stiffness, as well as the storage modulus, of the composites. The increase in stiffness decreased the damping factor compared to pure polyester.

- The thermogravimetry analysis of CIF reveals that the higher degradation (mass change of $50.13 \%$ ) of CI fibers happens in the third stage (between $203.16^{\circ} \mathrm{C}$ to $371.1^{\circ} \mathrm{C}$ ) with loss of cellulose and some part of lignin.

- The DMA test revealed that the pure polyester storage modulus is much lower than the CIFRCs in the glass transition region. This is because of the free molecular mobility of the polymer chains that can break the crosslinking between the molecular chains.

- The DMA result showed that the $30 \mathrm{~mm}$ fiber length reinforced composite has a higher storage modulus in the glassy plateau due to the higher interfacial bonding between fiber and matrix. 
- The loss modulus of pure polyester and higher fiber length is low owing to the lack of heat dissipation and the fiber length of $40 \mathrm{~mm}$ was found to have the highest value among all fiber lengths. This is due to the variation in the physical bond between the fiber and matrix.

- The TGA result envisaged that, up to $400^{\circ} \mathrm{C}$, the degradation of samples are due to the level of water loading in the composite and there is a significant improvement in the thermal stability beyond $400^{\circ} \mathrm{C}$.

- Among the various fiber lengths, the CIFRCs fabricated with the critical length of $30 \mathrm{~mm}$ fiber were found with an optimal value of modulus and damping factor.

- The SEM fractography results reveal that the major mechanism involved for mechanical failure are fiber pull out, matrix and fiber fractures.

\section{REFERENCES}

[1] Faruk O., Bledzki A.K., Fink H.P., Sain M.: Progress in Polymer Science 2012, 37, 1552. https://doi.org/10.1016/j.progpolymsci.2012.04.003

[2] Dittenber D.B., GangaRao H.V.S.: Composites Part A 2012, 43, 1419. https://doi.org/10.1016/j.compositesa.2011.11.019

[3] Rana R.S., Purohit R.: Materials Today: Proceedings 2017, 4, 3466.

https://doi.org/10.1016/j.matpr.2017.02.236

[4] Xu P., Yu Y., Liu D. et al.: Composites Science and Technology 2018, 163, 26.

https://doi.org/10.1016/j.compscitech.2018.05.009

[5] Balaji A.N., Nagarajan K.J.: Carbohydrate Polymers 2017, 174, 200. http://dx.doi.org/10.1016/j.carbpol.2017.06.065

[6] Kiruthika A.V.: Journal of Building Engineering 2017, 9, 91. https://doi.org/10.1016/j.jobe.2016.12.003

[7] Senthilkumar K., Saba N., Rajini N. et al.: Construction and Building Materials 2018, 174, 713.

https://doi.org/10.1016/j.conbuildmat.2018.04.143

[8] Lee D., Song Y.S.: Composites Part B: Engineering 2018, 146, 98. https://doi.org/10.1016/j.compositesb.2018.03.047

[9] Fu S., Yu B., Tang W. et al.: Composites Science and Technology 2018, 163, 141. https://doi.org/10.1016/j.compscitech.2018.03.020

[10] Sepe R., Bollino F., Boccarusso L., Caputo F.: Composites Part B: Engineering 2018, 133, 210. https://doi.org/10.1016/j.compositesb.2017.09.030

[11] Yan L., Chouw N., Huang L., Kasal B.: Construction and Building Materials 2016, 112, 168. https://doi.org/10.1016/j.conbuildmat.2016.02.182

[12] Pak S., Park S., Song Y.S., Lee D.: Composite Structures 2018, 193, 73.

https://doi.org/10.1016/j.compstruct.2018.03.020

[13] Paul S.A., Boudenne A., Ibos L. et al.: Composites Part A: Applied Science and Manufacturing 2008, 39, 1582. https://doi.org/10.1016/j.compositesa.2008.06.004

[14] Sair S., Oushabi A., Kammouni A. et al.: Case Studies in Construction Materials 2018, 8, 203.

https://doi.org/10.1016/j.cscm.2018.02.001

[15] Lavoratti A., Scienza L.C., Zattera A.J.: Carbohydrate Polymers 2016, 136, 955. https://doi.org/10.1016/j.carbpol.2015.10.008

[16] Ferreira M.V.F., Neves A.C.C., de Oliveira CG. et al.: Journal of Materials Research and Technology 2017, 6, 396. https://doi.org/10.1016/j.jmrt.2017.09.002

[17] Sreenivasan V.S., Ravindran D., Manikandan V., Narayanasamy R.: Materials \& Design 2011, 32, 2444. http://dx.doi.org/10.1016/j.matdes.2010.11.042

[18] Kumar M., Alok S., Jain S.K., Dixit V.K.: Asian Pacific Journal of Tropical Disease 2014, 4, S121. https://doi.org/10.1016/S2222-1808(14)60426-6

[19] Bhuvaneshwaran M., Sampath P.S., Suresh Sagadevan: Polimery 2019, 64, 93. https://dx.doi.org/10.14314/polimery.2019.2.2

[20] Jagushte G.S., Kamble N., Jadhav P. et al.: International Research Journal of Engineering and Technology 2017, 04 , 138.

[21] Gupta M.K., Singha R.: materialstoday: PROCEEDINGS 2017, 5, 6109. https://doi.org/10.1016/j.matpr.2017.12.216

[22] Bucheler D., Kaiser A., Henning F.: Composites Part B: Engineering 2016, 106, 218.

https://doi.org/10.1016/j.compositesb.2016.09.028

[23] Joseph K., Thomas S., Pavithra C.: Materials Letters 1992, 15, 224. https://doi.org/10.1016/0167-577X(92)90150-I

[24] Gupta M.K., Singh R.: materialstoday: PROCEEDINGS 2017, 5, 6109. https://doi.org/10.1016/j.matpr.2017.12.216

[25] Bhuvaneshwaran M., Subramani S.P., Palaniappan S.K. et al.: Journal of Natural Fibers 2019, 1-9. https://doi.org/10.1080/15440478.2019.1642826

[26] Boumediria H., Bezazia A., Del Pinob G.G. et al.: Carbohydrate Polymers 2019, 222, 114997. https://doi.org/10.1016/j.carbpol.2019.114997

Received 10 VI 2019.

Revised version 16 XII 2019. 